\title{
THE HEALING OF RICKE'TS COINCIDENT WITH LOW SERUM INORGANIC PHOSPHORUS
}

\author{
By GENEVIEVE STEARNS AND JULIAN D. BOYD \\ (From the Department of Pediatrics, College of Medicine, State University of Iowa, \\ Iowa City)
}

(Received for publication February 21, 1931)

Within the past year, roentgenological evidence of healing of rickets coincident with a persistently low level of serum inorganic phosphorus has been observed in 2 children. These findings are of importance in relation to the theories of bone formation.

The subjects of the study were 2 girls of 12 and 13 years of age, respectively, both of whom showed roentgenological, clinical and chemical evidence of active rickets. The serum calcium values of both children were within normal limits, the serum inorganic phosphorus markedly depressed. The children were given dietary treatment and kept under observation for a period of several months. During this time roentgenological evidence of marked healing of the bone was observed, but the serum inorganic phosphorus of each child remained essentially at the same low level.

\section{METHODS}

Blood was drawn before breakfast and the serum separated from the clot as rapidly as possible. Calcium was determined by the method of Kramer and Tisdall (1), allowing the serum to stand 24 hours after the addition of the oxalate. The method of Fiske and Subbarow (2) was used for inorganic phosphorus: protein was determined by microKjeldahl (3). All possible precautions were taken in order to insure accuracy in the determinations.

\section{RESULTS AND DISCUSSION}

Blood and metabolic studies of the 2 children were made at intervals during a period of several months. The values obtained for serum 
calcium and phosphorus are given in table I. Reproductions of the roentgenograms of the bones are shown in figures 1 and 2 . The films, as interpreted by representatives of the departments of roentgenology, orthopedics, and pediatrics, show marked evidence of progressive healing.

TABLE I

The serum calcium and inorganic phosphorus of two children during healing rickets

\begin{tabular}{|c|c|c|c|c|c|c|c|}
\hline \multicolumn{4}{|c|}{ D. C., 13 years } & \multicolumn{4}{|c|}{ M. N., 12 years } \\
\hline Date & $\begin{array}{l}\text { Cal- } \\
\text { cium }\end{array}$ & $\begin{array}{c}\text { Phos- } \\
\text { phorus }\end{array}$ & $\begin{array}{c}\text { Cal- } \\
\text { cium } \\
\times \\
\text { phos- } \\
\text { phorus }\end{array}$ & Date & $\begin{array}{l}\text { Cal- } \\
\text { cium }\end{array}$ & $\begin{array}{c}\text { Phos- } \\
\text { phorus }\end{array}$ & $\begin{array}{c}\text { Cal- } \\
\text { cium } \\
\text { p } \\
\text { phos- } \\
\text { phorus }\end{array}$ \\
\hline & $\begin{array}{c}m g m . \\
\text { per } \\
\text { cent }\end{array}$ & $\begin{array}{c}\text { mgm. } \\
\text { per } \\
\text { cent }\end{array}$ & & & $\begin{array}{c}m \text { mgm. } \\
\text { per } \\
\text { cent }\end{array}$ & $\begin{array}{c}m g m . \\
\text { per } \\
\text { cent }\end{array}$ & \\
\hline July 17,1929 & 9.9 & 3.2 & 31.7 & January 3,1930 & 11.3 & 2.2 & 24.9 \\
\hline July 26, 1929 & 11.4 & 3.0 & 34.2 & & & & \\
\hline & & & & February 12,1930 & 10.2 & 2.2 & 22.4 \\
\hline October 11, 1929 & 10.6 & 3.0 & 31.8 & February 18,1930 & 10.4 & 2.4 & 25.0 \\
\hline October 18,1929 & 10.3 & 3.1 & 31.9 & & & & \\
\hline October 29, 1929 & 10.8 & 2.5 & 27.0 & June 17,1930 & 10.8 & 2.0 & 21.6 \\
\hline & & & & June 24,1930 & 11.1 & $2.2^{*}$ & 24.4 \\
\hline November 5, 1929 & 10.9 & 2.9 & 31.6 & & & & \\
\hline November 17, 1929 & 10.5 & 2.8 & 29.4 & August 5, 1930 & 11.2 & 3.2 & 35.8 \\
\hline February 18,1930 & 9.6 & 2.4 & 23.0 & November 11,1930 & 10.9 & $2.7 \dagger$ & 29.4 \\
\hline March 4, 1930 & 10.6 & 2.8 & 29.7 & & & & \\
\hline March 25, 1930 & 10.2 & 2.7 & 27.5 & & & & \\
\hline April 1, 1930 & 9.9 & 2.6 & 25.7 & & & & \\
\hline April 9, 1930 & 10.3 & 2.8 & 28.8 & & & & \\
\hline April 14, 1930 & 10.9 & 3.1 & 33.8 & & & & \\
\hline
\end{tabular}

* Phosphatase 0.42 units (normal 0.12-0.21).

$\dagger$ Total acid soluble phosphorus, whole blood, $21.8 \mathrm{mgm}$. per cent.

Detailed reports of the clinical findings and studies of the mineral metabolism of the 2 children are reported elsewhere (4). The calcium and phosphorus findings, however, may be summarized briefly here. The child D. C., in November, 1929, after more than 3 months of antirachitic treatment, was found to be retaining $25 \mathrm{mgm}$. of calcium per kilo daily, with a high intake of this element. The daily retention 
of phosphorus was still better, $30 \mathrm{mgm}$. per kilo. In March, 1930, after the continuation of the same treatment, the daily retentions of calcium and phosphorus were 30 and $21 \mathrm{mgm}$. per kilo respectively. The addition of 60 drops of viosterol ${ }^{1}$ daily increased these retentions

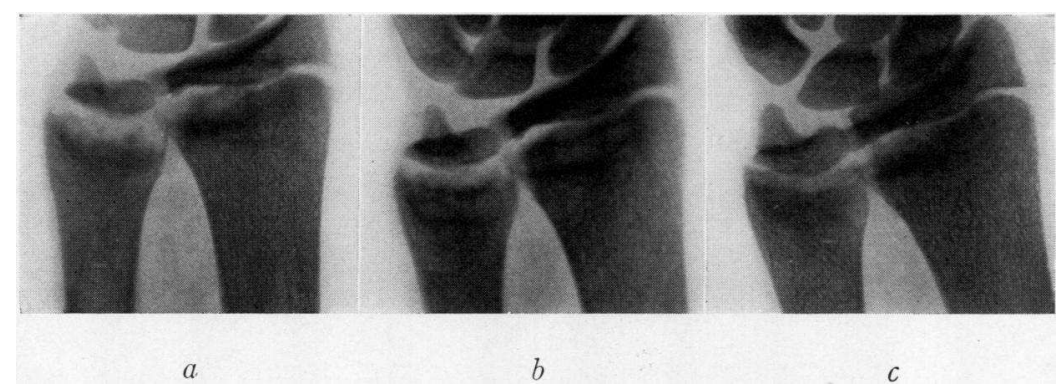

Fig. 1. Roentgenograms of the Wrist of D. C.

$a$ was taken July 24,$1929 ; b$ was taken October 4,$1929 ; c$ was taken March 31 , 1930. During this time the child received antirachitic treatment. Metabolic observations indicated adequate retention of calcium and phosphorus, yet the serum inorganic phosphorus was consistently low (2.5 to $3 \dot{\mathrm{mgm}}$. per $100 \mathrm{cc}$.) throughout the entire period.

to 39 and $29 \mathrm{mgm}$. per kilo respectively. The child M. N. had been receiving antirachitic treatment for about 5 weeks previous to the first study. The daily retentions of calcium and phosphorus first observed were 24 and $15 \mathrm{mgm}$. per kilo. Four months later, with no change in diet, but with sunlight treatment in addition to the cod liver oil for one month previous to the observation period, the daily calcium retention had increased to $30 \mathrm{mgm}$. per kilo, the phosphorus retention remaining at the same level as in the previous study. The retentions of calcium and phosphorus observed in both children were thus well above the average normal retention as given by Sherman (5), and may be considered adequate for the healing of rickets. Serum analyses for calcium and inorganic phosphorus were made at intervals during the periods of study and are reported in table I. Of the other blood analyses, the values obtained for carbon dioxide capacity, for nonprotein nitrogen and for chloride were always within normal limits. Determinations of $\mathrm{pH}$ were not made.

\footnotetext{
1 The viosterol used in these studies was supplied by Mead Johnson and Company.
} 


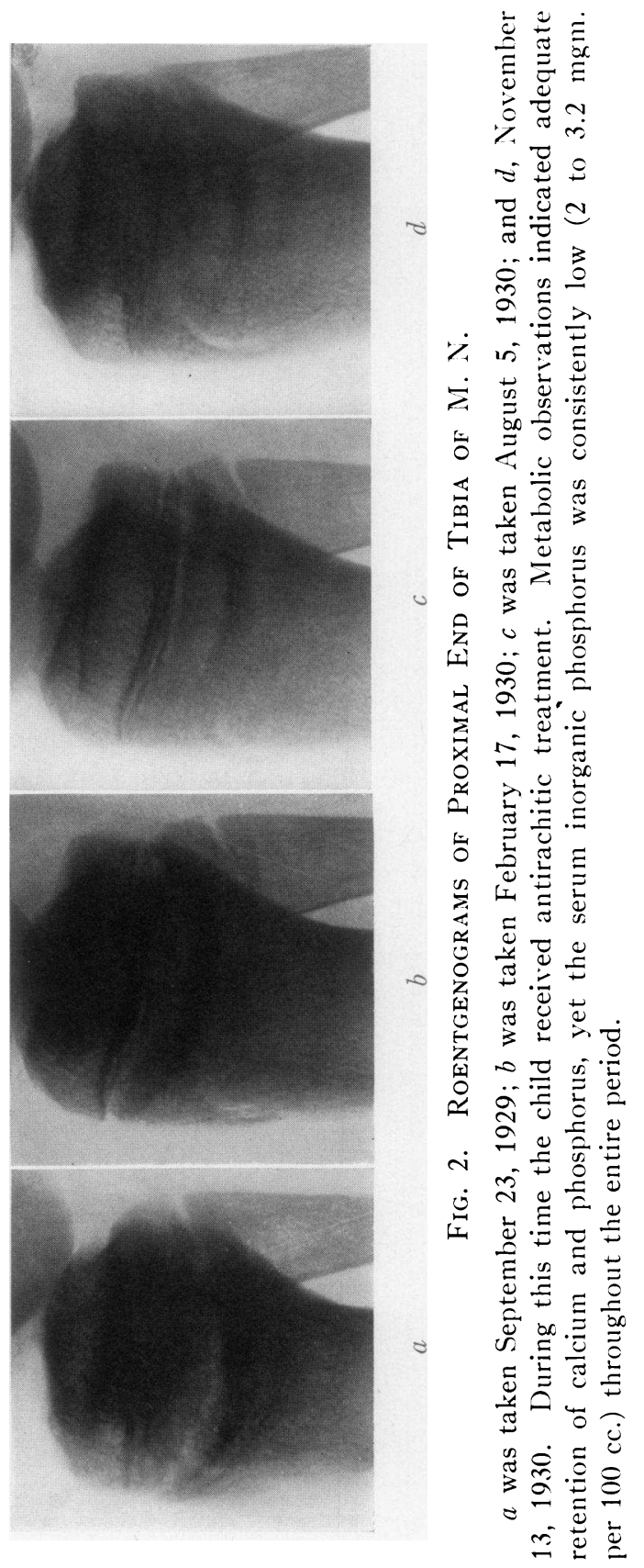


The daily retentions of calcium and phosphorus observed in each child during these studies were amply sufficient to provide the minerals necessary for calcification of bone. It is evident from the roentgenograms that such calcification took place. Nevertheless the serum inorganic phosphorus of each child remained approximately at the same level, fluctuating between 2 and $3 \mathrm{mgm}$. per cent. The existence of such values in cases of healing rickets is noteworthy because it has been generally accepted heretofore that serum phosphorus values as low as these are not compatible with healing rickets, but are indicative of rachitic activity. Almost as striking is the fact that in the child D. C. the rickets was active during the late summer, and that despite the low serum inorganic phosphorus, the period of marked healing occurred during the late winter-a reversal of the usual seasonal activity and healing of rickets.

A careful review of the literature has disclosed but two other reports of healing rickets concomitant with low serum inorganic phosphorus, and in one of these reports the low phosphorus was but a transitory finding. Howland and Kramer (6) in their original series of observations of serum calcium and inorganic phosphorus in infantile rickets listed 2 children with "unmistakable evidence of healing" when the serum inorganic phosphorus values were $3.2 \mathrm{mgm}$. per cent. The authors made no special comment on these cases but concluded that a serum inorganic phosphorus of $3 \mathrm{mgm}$. per cent or less was indicative of active rickets. Gargill and his collaborators (7) have recently reported a case of osteomalacia, or adult rickets, in a 38 year old woman, wherein definite increase in density of bone was observed during a period of ten months. The serum inorganic phosphorus of the patient remained consistently low during the entire study, varying from 2.16 to $2.64 \mathrm{mgm}$. per cent. Though this fact occasioned no comment by the authors, we believe it to be of significance.

On the other hand, Hess, Weinstock, Rivkin, and Gross (8) have observed active rickets in infants whose serum calcium and inorganic phosphorus levels were quite normal. By proper manipulation of the diet, these authors were able to increase the serum inorganic phosphorus of rachitic rats to normal values, and yet delay markedly the healing of the rachitic lesions. These results were interpreted as indicative of the fact that both local and systemic factors were involved in the production of rickets. 
The occurrence of calcification of bone despite a low serum inorganic phosphorus is most readily explained by considering that the deposit might consist almost wholly of calcium carbonate, instead of the normal calcium phosphate-carbonate complex. This explanation, however, is not satisfactory in the cases studied by us, in view of the large amounts of phosphorus retained by each child. The amount of phosphorus utilized in the production of tissues other than bone may be estimated roughly from the retention of nitrogen, the ratio of $\mathrm{N}: \mathrm{P}$ in the soft tissues being approximately $17: 1(9)$. The maximum retention of nitrogen observed in either child, $87 \mathrm{mgm}$. per kilo, can account for only about $5 \mathrm{mgm}$. per kilo of the retained phosphorus. A daily storage of from 10 to $24 \mathrm{mgm}$. of phosphorus per kilo body weight in tissues other than bone seems even more difficult to reconcile with the maintenance of the low serum inorganic phosphorus than does its storage in bone.

If it may be granted that at least a part of the deposit must consist of calcium phosphate, the occurrence of this marked deposition of minerals at the metaphyses, coincident with the maintenance of a low serum inorganic phosphorus, must have a direct bearing upon the theories of calcification of bone. Any theory, to be adequate, must explain the calcification which occurs under unusual conditions such as those described here.

The modern theories of normal calcification of bone may be divided into 2 groups: those concerned primarily with conditions existing in serum, as related to the probable precipitation of insoluble calcium salts in bone; and those concerned only with conditions at the site of bone formation. In the first group, Shear and Kramer (10) have brought forward evidence to prove that the calcium phosphate compound of blood serum is the dicalcium, instead of the tricalcium salt. According to these authors, the serum of children is normally saturated, or nearly saturated, with dicalcium phosphate. Calcification of bone was obtained in vitro only when the bone was immersed in solutions containing sufficient calcium and phosphate ions so that the ion product $\left(\mathrm{Ca}^{\prime \prime}\right) \times\left(\mathrm{HPO}_{4}{ }^{-}\right)$was greater than $2.5 \times 10^{-6}$ an ion product corresponding to an empirical product of calcium $\times$ phosphorus $=35$. In serum, the calcium is not wholly ionized; therefore the empirical product of serum calcium and phosphorus represents a 
greater value than the ion product $\left(\mathrm{Ca}^{\prime \prime}\right) \times\left(\mathrm{HPO}_{4}=\right)$. Because calcification did not take place in vitro when the empirical product calcium $\times$ phosphorus was less than 35 , these authors postulated that calcification in vivo would not occur until the empirical product reached a value of 35 or greater.

An examination of the empirical products calcium $\times$ phosphorus of the serum of the child $D$. C. (table I) reveals but 2 values approximating 35 and one of these values was obtained when the rachitic process was most active. A product of 36 was obtained with the second child M. N., during the period of greatest healing. Other values for this product obtained during healing were as low as 22 . According to the calculations of Shear and Kramer, the serums of both children were undersaturated with dicalcium phosphate to a degree that would preclude calcification entirely. Yet calcification occurred in both cases, as is shown in figures 1 and 2.

In 1925, Holt, La Mer, and Chown (11) studied the serum calcium and inorganic phosphorus relative to the solubility product of tricalcium phosphate, concluding that normal serum is supersaturated with tricalcium phosphate to the extent of about 200 per cent, and that even in active rickets the serum is still supersaturated with tricalcium phosphate. Holt (12) suggested that calcification is not entirely arrested in active rickets, but that it is so retarded that bone growth exceeds it in activity, thus producing the inadequately calcified bone characteristic of rickets.

It might be argued, from this theory, that in these cases of late rickets, growth of bone was slow enough so that even though calcification was much decreased, it was still carried on sufficiently to make a noticeable difference in the density of the bone during the period studied. Such an explanation is unsatisfactory in many respects. The first roentgenograms are typical of active rickets. The child D. C. grew an inch in height during the 9 months observation period, so the growth of bone was not inordinately slow. The retentions of calcium and phosphorus observed in each child were of the order of healing rickets; the calcification which occurred was apparently of the type characteristic of healing, not of active rickets. In every respect excepting the low serum inorganic phosphorus, the picture resembles the healing observed in infantile rickets when the serum phosphorus 
has increased to normal, so that the idea of depressed calcification does not seem applicable to these cases.

Our knowledge of the chemical composition of the minerals of bone has been much clarified by the study of $\mathrm{x}$-ray spectrograms of bone. Taylor and Sheard (13) and, more recently, Roseberry, Hastings, and Morse (14) have shown that bone has a crystal structure fundamentally the same as that of other members of the apatite series. The latter authors give the probable composition of bone as $\mathrm{CaCO}_{3}: n \mathrm{Ca}_{3}\left(\mathrm{PO}_{4}\right)_{2}$, where $n$ is not less than 2 nor greater than 3 . No evidence of the presence of $\mathrm{CaHPO}_{4}$ or $\mathrm{CaCO}_{3}$ in bone was found by either group of investigators, although Roseberry and his colleagues studied newlydeposited, as well as old bone. In studies of the solubility relationships of bone salts, Taylor and Sheard (13) recommend that the solubility product of podolite, $3 \mathrm{Ca}_{3}\left(\mathrm{PO}_{4}\right)_{2}: \mathrm{CaCO}_{3}$, be used, rather than that of brushite, $\mathrm{CaHPO}_{4}: 2 \mathrm{H}_{2} \mathrm{O}$, or of tricalcium phosphate. We are not aware of any published studies comparing the relationships of serum calcium and inorganic phosphorus with the solubility product of podolite.

A true concept of the physicochemical conditions at the point of bone formation cannot be gained from examination of the serum alone. The concentration of calcium and phosphorus in other body fluids differs from that of the serum (15), the differences being largely accounted for by the decreased content of protein, which, according to the Donnan equilibrium, necessitates a rearrangement of electrolytes. Normally the amounts of both calcium and inorganic phosphorus are lower in other body fluids than in serum. In the patients herein reported, it was thought possible that sufficient alterations in the physicochemical system of the body fluids might have occurred to compensate, in some measure at least, for the low serum inorganic phosphorus. Analysis of fluids at the site of bone formation was, of course, impossible, but it was felt that any marked disturbance of equilibrium would be reflected in all of the body fluids. With this point in mind, simultaneous samples of blood and cerebrospinal fluid of $M$. N. were taken during the period of greatest healing of the rachitic lesions. The analyses of protein, calcium, and inorganic phosphorus, together with those of a nonrachitic child of the same age, are given in table II. The serum protein of the rachitic child is somewhat de- 
TABLE II

Calcium, inorganic phosphorus, and protein in serum and cerebrospinal fluid of a rachitic child and of a non-rachitic child of the same age

\begin{tabular}{l|c|c|c}
\hline \multicolumn{1}{c|}{ Fluid } & Calcium & Phosphorus & Protein \\
\hline & mgm. per cent & mgm. per cent & grams per cent \\
M. N., rachitic, June 17, 1930 & & & \\
Serum & 10.8 & 2.0 & 6.6 \\
Cerebrospinal fluid & 6.0 & 0.6 & .011 \\
Ratio Serum: Cerebrospinal fluid & 1.8 & 3.32 & 600. \\
& & & \\
K. K., non-rachitic, June 17, 1930 & & & \\
& & & \\
Serum & 11.2 & 4.4 & 8.1 \\
Cerebrospinal fluid & 1.75 & 3.14 & 735. \\
Ratio Serum: Cerebrospinal fluid & & & \\
\end{tabular}

creased, the serum inorganic phosphorus markedly so. The phosphorus of the spinal fluid is very low, but the ratio of serum phosphorus: spinal fluid phosphorus is practically the same in the rachitic as in the nonrachitic child. Reasoning by analogy, it appears that the inorganic phosphorus content of the fluids at the metaphyses must also be abnormally low.

Two of the modern theories of bone calcification are concerned chiefly with the conditions in the ossifying cartilage. According to the theory of Freudenberg and György (16), calcification takes place through the formation of intermediary compounds with protein, a calcium-protein compound being formed first, which reacts with phosphate and carbonate ions to form a second complex. This latter compound breaks down slowly, depositing calcium phosphate and carbonate, and liberating the protein to combine with more calcium and begin the cycle again. The rate of formation of these intermediary complexes would, of course, vary with the amount of available calcium and phosphate ions; therefore this theory offers no explanation of the phenomenon of healing without coincident increase in serum phosphate.

Robison and his collaborators (17) discovered the presence in ossifying cartilage of an enzyme capable of hydrolyzing certain phosphate esters. From their experimental findings, these investigators suggested that through the action of this enzyme, the concen- 
tration of phosphate ion at the point of calcification could be increased to such an extent that the solubility product of calcium phosphate would be exceeded and precipitation take place. These authors also demonstrated that in rickets of rats the amount of bone phosphatase is not decreased but is probably increased. The failure of calcification in rickets, therefore, is probably not due to lack of enzyme, but to some other factor, as a deficient amount of substrate.

Phosphate esters which can be hydrolyzed by the bone phosphatase are found in the red corpuscles, leucocytes, and to a slight extent in the blood plasma (18). The amounts of these esters in other body fluids are not known. Small amounts of phosphatase having the same properties as bone phosphatase and presumably identical with it are found in plasma (19). Kay (20) has recently published data showing that in certain diseases of man wherein there is destruction of bone, or lack of deposition of bone salts, the phosphatase content of plasma is markedly increased. In 10 cases of infantile rickets, reported by him, the plasma phosphatase averaged 0.95 units (the normal for this age group is $0.17-0.34$ units); in one case of adolescent rickets the very high value of 2.4 units was observed. The plasma phosphatase decreases when the child is given antirachitic dietary treatment (21). A study of the phosphatase content of the blood of our patients seemed desirable. Through the courtesy of Dr. Kay, an analysis of the phosphatase content of the plasma of M. N. was obtained. The child had been receiving antirachitic treatment for about 6 months and evidences of healing were very definite. The value found, 0.42 units, is definitely above normal (0.12-0.20 units, normal adult range) but far below the values noted in Kay's cases of untreated rickets. If the amount of plasma phosphatase is indicative of the amount available in bone, there should be sufficient enzyme present for normal calcification.

In order to account for the calcification observed in these 2 children with late rickets according to Robison's theory, it is necessary to postulate the hydrolysis of an unusually large amount of phosphate ester to provide sufficient phosphate ion at the metaphyses for the precipitation of calcium phosphate. Such an increased hydrolysis is within the realms of possibility, although the data obtained are insufficient either to support or to deny such a conclusion. A single 
determination of total acid-soluble phosphorus of whole blood of M. N. indicated that the total ester phosphorus was within normal limits. Whether the fraction of phosphate ester which can be hydrolyzed by bone enzyme is normal or below normal has not been determined. It is hoped that these studies may be continued.

\section{SUMMARY}

The clinical healing of late rickets coincident with a persistently low level of serum inorganic phosphorus has been observed in 2 children.

The retention of calcium and phosphorus observed in each child was considered amply sufficient for the building of bone.

The data herein reported do not offer evidence definitely substantiating any of the prevalent theories of bone calcification; moreover, it is difficult to reconcile certain of these theories with the findings.

\section{BIBLIOGRAPHY}

1. Kramer, B., and Tisdall, F. F., J. Biol. Chem., 1921, xlvii, 475. A Simple Technique for the Determination of Calcium and Magnesium in Small Amounts of Serum.

2. Fiske, C. H., and Subbarow, Y., J. Biol. Chem., 1925, 1xvi, 375 . The Colorimetric Determination of Phosphorus.

3. Hawk, P. B., and Bergeim, O., Practical Physiological Chemistry. Philadelphia, Blakiston's, 1926, 9th ed., p. 398.

4. Stearns, G., Oelke, M. J., and Boyd, J. D., Am. J. Dis. Child., 1931, xlii, 88. A Study of Mineral Metabolism in Late Rickets.

5. Sherman, H. C., and Hawley, E., J. Biol. Chem., 1922, liii, 375. Calcium and Phosphorus Metabolism in Childhood.

6. Howland, J., and Kramer, B., Am. J. Dis. Child., 1921, xxii, 105. Calcium and Phosphorus in the Serum in Relation to Rickets.

7. Gargill, S. L., Gilligan, D. R., and Blumgart, H. L., Arch. Int. Med., 1930, xlv, 879. Metabolism and Treatment of Osteomalacia.

8. Hess, A. F., Weinstock, M., Rivkin, H., and Gross, J., Proc. Soc. Exp. Biol. and Med., 1929-30, xxvii, 140. Observations Suggesting a Local Factor in Pathogenesis and Healing of Rickets.

J. Biol. Chem., 1930, lxxxvii, 37. The Lack of Relationship between the Development and Cure of Rickets and the Inorganic Phosphorus Concentration of the Blood.

9. Schabad, J. A., Arch. f. Kinderheilk., 1910, lii, 68: Zur Bedeutung des Kalkes in der Pathologie der Rachitis.

10. Shear, M. J., and Kramer, B., J. Biol. Chem., 1928, lxxix, 125 . Composition of Bone. III. Physicochemical Mechanism. 
11. Holt, L. E., Jr., La Mer, V. K., and Chown, H. B., J. Biol. Chem., 1925, lxiv, 509, 567. Studies in Calcification. I. The Solubility Product of Secondary and Tertiary Calcium Phosphate under Various Conditions. II. Delayed Equilibrium between the Calcium Phosphates and its Biological Significance.

12. Holt, L. E., Jr., J. Biol. Chem., 1925, lxiv, 579. Studies in Calcification. III. A Quantitative Study of the Equilibria Concerned with the Calcification of Bone.

13. Taylor, N. W., and Sheard, C., J. Biol. Chem., 1929, lxxxi, $479 . \quad$ Microscopic and X-Ray Investigations on the Calcification of Tissue.

14. Roseberry, H. H., Hastings, A. B., and Morse, J. K., J. Biol. Chem., 1931, xc, 395. X-Ray Analysis of Bones and Teeth.

15. Arnold, R. M., and Mendel, L. B., J. Biol. Chem., 1927, lxxii, 189. Interrelationships between the Chemical Composition of the Blood and the Lymph of the Dog.

Merritt, H. H., and Bauer, W., J. Biol. Chem., 1931, xc, 215. The Equilibrium between Cerebrospinal Fluid and Blood Plasma. III. The Distribution of Calcium and Phosphorus between Cerebrospinal Fluid and Blood Serum.

16. Freudenberg, E., and György, P., Biochem. Ztschr., 1920, cx, 299; 1921, cxv, 96; 1921, cxviii, 50; 1921, cxxi, 131, 142; 1921, cxxiv, 299. Über Kalkbindung durch Tierische Gewebe. I-VI.

György, P., Jahrb. f. Kinderheilk., 1923, cii, 145. Über Rachitis und Tetanie.

17. Robison, R., Biochem. J., 1923, xvii, 286. The Possible Significance of Hexosephosphoric Esters in Ossification.

Robison, R., and Soames, K. M., Biochem. J., 1924, xviii, 740. The Phosphoric Esterase of Ossifying Cartilage.

18. Kay, H. D., and Robison, R., Biochem. J., 1924, xviii, 755. The Action of the Bone Enzyme on the Organic Phosphorus Compounds in Blood.

Kay, H. D., Brit. J. Exp. Path., 1926, vii, 177. The Function of a Phosphatase in Bone Formation.

Kay, H. D., and Byrom, F. B., Brit. J. Exp. Path., 1927, viii, 240. Blood Phosphorus in Health and Disease. I. The Distribution of Phosphorus in Human Blood in Health.

19. Martland, M., Hansman, F. S., and Robison, R., Biochem. J., 1924, xviii, 1152 . The Phosphoric Esterase of Blood.

20. Kay, H. D., J. Biol. Chem., 1930, lxxxix, 249. Plasma Phosphatase. II. The Enzyme in Disease, Particularly in Bone Disease.

21. Kay, H. D., Personal Communication. 